\title{
Improving board assurance of technical and operational risks in mining
}

\author{
AC Atkins Alex Atkins \& Associates Pty Ltd, Australia \\ M Ritchie Professional Auditor, Australia
}

\begin{abstract}
There are gaps in board assurance on technical and operational risk in mining. There are gaps in current environmental social governance (ESG) and enterprise risk management, especially for geotechnical risk.

Chief risk officers (CROs) and audit teams who report to the board's audit and risk committee are often staffed by accountants and lawyers who provide an essential service, but may not appreciate the science, technology, engineering and maths (STEM) aspects of mining, including its technical complexity, variability and uncertainty. This demography tends to focus on commercial, financial and legal risk. Their skill sets mean they may have a blind spot on how STEM mining risks have an impact, including on company performance and innovation (opportunity risks). Additionally, with the digital transformation of mining underway, there is a risk the disrupting 'digital natives' (i.e. deep domain experts on digital technology) also lack an understanding of the technical and operational risks of mining and may inadvertently create new risks.

Understanding risk in mining requires technical and operational expertise in mining engineering, life-of-mine planning, geotechnical engineering, geology and metallurgy. These professionals need to work alongside traditional risk practitioners and auditors to develop new ways to provide transparency, accountability and assurance to mining company boards.
\end{abstract}

Keywords: board assurance, audit, technical risk, operational risk, Global Reporting Initiative

\section{Introduction}

Mining company directors are responsible for setting the company goals, appointing the CEO, oversight of the company's management including management of risk, and reviewing at reasonable intervals the company's progress towards attaining its goals (Baxt 2012, p. 111). It is also the board's responsibility to set the company's 'risk appetite' (the type and level of risks it is prepared to tolerate). According to ISO 31000:2018 (International Organization for Standardization (ISO) 2018), risk is the 'effect of uncertainty on objectives'.

"The independence of the board establishes the ability of the corporation to uphold its responsibilities to third parties when they conflict with the interests of shareholders" (Mayer 2013). The independence of boards, with the right diversity of thought and skills balance to ask the right questions at the right time, is something shareholders and regulators expect and are constantly monitoring, particularly on management of risk and on timely and balanced disclosure, as outlined by the ASX Corporate Governance Principles and Recommendations (ASX 2014a).

Over the past decade, there has been a growth in class actions relating to mining company director's duties of care and diligence (including appropriate risk management), such as the:

- Newcrest class action settled in 2014 for AUD 36M (Slater \& Gordon 2016) for: "misleading or deceptive conduct by providing production guidance without reasonable grounds" and for "breaching continuous disclosure obligations" (i.e. allegedly due to acquisitions which were subsequently substantially written down). 
- BHP class action (ongoing) (Ker 2018a) for failing to act upon or to disclose information in an independent engineer's report on the risk of failure of the Samarco tailings dams, which led to material losses and damages.

There are "severe difficulties faced by directors under strict liability/reversal of onus of proof legislation" (Baxt 2012, p. 130) and it is "very difficult for directors to obtain comprehensive insurance coverage with regard to breaches of the law" (Baxt 2012, p. 164). This is a key reason why board assurance activities are undertaken. It is not just to inform and warn directors of impending issues, but also to provide evidence that directors executed their fiduciary duties.

With mines safety legislation in Australia becoming increasingly risk-based and less prescriptive, it is important to ensure a systemic framework of identification, management and assurance of risk management is in place across the organisation. The aim is to ensure that appropriate mechanisms exist to demonstrate that all risks are identified, and their mitigating controls are monitored for their effectiveness.

Many mining companies are adhering to the Critical Controls Framework promulgated by the International Council of Mining and Metals (ICMM 2018). The critical controls approach is more than just assurance. It is intended to be a process that facilitates:

- The selection of the right controls.

- Having the controls adequately specified (i.e. specific, measurable, auditable and verifiable).

- Monitoring and maintaining controls so they sustainably perform to required specifications.

- Assurance activities that include assessing the effectiveness of controls to mitigate risk.

For catastrophic mining risks, each of these activities require the input of deep domain expertise.

Many mining companies have, or are, adopting the Workplace Health and Safety (WHS) Management Systems approach codified in the Model WHS Act (Safe Work Australia 2016), which suggests a framework for (Quinlan 2014, p. 50-51):

- Principal hazard management plans (i.e. for bespoke risks depending on the unique characteristics of the mine, such as geotechnical risks).

- Principal control plans (i.e. for more standardised risks like mechanical, electrical, health, environmental, ventilation, etc.).

Directors should ensure their company has a mature risk management framework which provides a level of assurance that risks are being managed appropriately. If due diligence is not executed in an auditable fashion, there is a risk of company directors and officers facing steep penalties, criminal charges, class actions and/or regulatory action. Board assurance of technical and operational risks should be high on the agenda of mining company boards.

Understanding 'what can go wrong' and 'what must go right' in the technical and operational aspects of mining is the domain of technical experts such as mining engineers, geologists, geotechnical engineers, metallurgists, mining specific environmental scientist, etc. These domain experts should drive the assurance process, preferably from the board level. Mining is technically complex - disasters can and do happen.

\section{Main causes of mine disasters}

Due to the resulting community backlash in the wake of disasters:

"Catastrophic events like methane or coal dust explosions and fires; methane outbursts; water inrush and flooded workings; roof collapse and rockfalls; and entrapment (due to roof collapse, blocked entrances and shafts) have been a recurring impetus for reforming mine safety legislation" (Quinlan 2014, p. 38). 
When mining disasters happen, the mining industry, as a whole, loses a degree of its social licence to operate (SLTO), which is essentially permission from governments, communities, staff, customers and suppliers to undertake particular activities. When SLTO is lost, government permits are revoked or not approved, resource nationalism escalates where gross inequity is suspected, and staff turnover and strikes become common or the industry cannot recruit new professionals. Suppliers and/or customers may boycott the company if certain standards are not perceived to be upheld (e.g. environmental and social governance (ESG)). Loss of SLTO can be due to specific reasons (e.g. tailings storage facility (TSF) failures or rockfalls where miners are entrapped or killed) or unspecific reasons (e.g. pattern of avoiding meeting social and economic obligations in countries of operation).

Many mine accidents and disasters are due to geotechnical engineering issues, including:

- Tailings dam failures, e.g. Samarco 2015 (Morgenstern et al. 2016).

- Rockfalls, e.g. Beaconsfield 2006 (Chandler 2009).

- Inrush, e.g. Bronzewing 2000 (DMP 2000a; Hope 2002).

- Seismicity, e.g. Cadia 2017, 2018 (Dyson 2017; Newcrest Mining Limited 2018).

- Airblast, e.g. Northparkes 1999 (SIMTARS 1999; DMP 2000b; Bailey 2003; Hebblewhite 2003).

Non-geotechnical engineering issues, such as poor ventilation, fire and explosion, also feature highly in mine disaster literature (e.g. Pike River, 2010 (Panckhurst et al. 2012) and Moura, 1994 (Hair 2016)) and many more including inundation/inrush, machinery incidents, electrocution, falls from height and entrapment in confined spaces (Quinlan 2014, pp. 12 and 84).

As part of a concerted national effort to protect and enhance the Australian mining industry's reputation for world's best practice in terms of productivity, safety, health, environment and communities (HSEC) performance, Australian mines safety legislation was to be harmonised, but harmonised safety legislation is yet to eventuate (Atkins et al. 2016). The only thing that is relatively standard across the country is compliance with (non-mandatory) international standards for safety and risk management and the industry's requirement for itself and its service providers to be certified for:

- ISO 18001:2007 Occupational Health and Safety Management System (International Organization for Standardization (ISO) 2007) (or AS/NZS 4801:2001 (Standards Australia 2001)) - which on 12 March 2018 was superseded by ISO 45001:2008 Occupational Health and Safety Management Systems -- Requirements with Guidance for Use (ISO 2008).

- AS/NZS ISO 31000:2018 Risk Management (ISO 2018).

This certification is achieved by successful compliance, as validated by ISO audits, which must be carried out by certified practitioners. These ISO audits can be merged with technical compliance audits, such as the WA Department of Mines, Industry Regulation and Safety's (WA DMIRS) high impact function audits (see Atkins \& Webster-Smith 2011) to create technically specific assurance. But as many safety auditors are not mining STEM professionals, this is a rare practice.

According to UQR!SK (2018):

"Baselining and benchmarking exercises done to date have identified that a range of approaches are being used in different industries to measure the effectiveness of risk controls that are critical in preventing or mitigating catastrophic events. These approaches range from qualitative to quantitative. However, there is currently no consensus in the Australian mining sector on how to do it. It is also unclear what methods from other industries will translate to the mining industry."

Stacey et al. (2007) argued that board members and executive teams do not have to understand the technical details of mining as long as they are provided with advice from technical experts in terms they understand 
(i.e. probability of failure, monetary terms). But how do boards and management know what assurance to request if 'they don't know what they don't know'?

We now consider traditional audit and assurance standards that accountants and lawyers follow and ask you to think about whether that can provide appropriate assurance as to whether technical and operational risks in mining are being managed appropriately to prevent mine disasters.

\section{$3 \quad$ Audit and assurance standards}

\subsection{Existing standards for audit and risk practitioners}

Table 1 summarises existing standards which guide traditional audit and risk practitioners when they scope and plan internal audits, external (financial statement) audits or other board assurance activities. This is the focus of traditional chief financial officers, chief risk officers (CROs) and board audit and risk committees and their assurance providers, which are normally lacking mining domain experts such as mining engineers, geologists, geotechnical engineers and metallurgists.

Table $1 \quad$ Risk and assurance standards

\begin{tabular}{|c|c|c|}
\hline Name & Issued by & Summary of contents and aim \\
\hline $\begin{array}{l}\text { International } \\
\text { Standards for the } \\
\text { Professional } \\
\text { Practice of } \\
\text { Internal Auditing } \\
\text { (Standards) } \\
\text { (IIA 2017) }\end{array}$ & $\begin{array}{l}\text { International } \\
\text { Internal Audit } \\
\text { Standards } \\
\text { Board (Institute } \\
\text { of Internal } \\
\text { Auditors) }\end{array}$ & $\begin{array}{l}\text { The purpose of the Standards is to: } \\
\text { - Guide adherence with the mandatory elements of the } \\
\text { International Professional Practices Framework. } \\
\text { - Provide a framework for performing and promoting a broad } \\
\text { range of value-added internal auditing services. } \\
\text { - Establish the basis for the evaluation of internal audit } \\
\text { performance. } \\
\text { - Foster improved organisational processes and operations. } \\
\text { The Standards are a set of principles-based, mandatory requirements } \\
\text { consisting of: } \\
\text { - Statements of core requirements for the professional practice } \\
\text { of internal auditing and for evaluating the effectiveness of } \\
\text { performance that are internationally applicable at } \\
\text { organisational and individual levels. } \\
\text { - Interpretations clarifying terms or concepts within the } \\
\text { Standards. }\end{array}$ \\
\hline $\begin{array}{l}\text { Auditing } \\
\text { Standard ASA } \\
260: \\
\text { Communication } \\
\text { with Those } \\
\text { Charged with } \\
\text { Governance } \\
\text { (AUASB 2017a) }\end{array}$ & $\begin{array}{l}\text { Australian } \\
\text { Government: } \\
\text { Auditing and } \\
\text { Assurance } \\
\text { Standards } \\
\text { Board (AUASB) }\end{array}$ & $\begin{array}{l}\text { This Auditing Standard deals with the auditor's responsibility to } \\
\text { communicate with those charged with governance in an audit of a } \\
\text { financial report. Although this Auditing Standard applies irrespective of } \\
\text { an entity's governance structure or size, particular considerations } \\
\text { apply where all of those charged with governance are involved in } \\
\text { managing an entity, and for listed entities. Communication by the } \\
\text { auditor does not relieve management of this responsibility. } \\
\text { Limitation: only applies to audits of financial information (current or } \\
\text { historical) and only matters arising from the audit need to be } \\
\text { communicated. }\end{array}$ \\
\hline
\end{tabular}




\begin{tabular}{|c|c|c|}
\hline Name & Issued by & Summary of contents and aim \\
\hline \multirow{2}{*}{$\begin{array}{l}\text { ASA 265: } \\
\text { Communicating } \\
\text { Deficiencies in } \\
\text { Internal Control } \\
\text { to Those Charged } \\
\text { with Governance } \\
\text { and Management } \\
\text { (AUASB 2013) }\end{array}$} & & $\begin{array}{l}\text { Establishes specific requirements regarding the communication of } \\
\text { significant deficiencies in internal control the auditor has identified } \\
\text { during the audit to those charged with governance (that may result in } \\
\text { material misstatement of the financial statements). }\end{array}$ \\
\hline & & $\begin{array}{l}\text { Limitation: only applies to audits of financial information (current or } \\
\text { historical) and only matters arising from the audit need to be } \\
\text { communicated. }\end{array}$ \\
\hline $\begin{array}{l}\text { Guidance on } \\
\text { Assurance } \\
\text { Engagements } \\
\text { (including } \\
\text { Greenhouse Gas } \\
\text { Statements and } \\
\text { Water } \\
\text { Accounting } \\
\text { Reports) - } 3000 \\
\text { series (AUASB } \\
\text { 2017b) }\end{array}$ & $\begin{array}{l}\text { Australian } \\
\text { Government: } \\
\text { AUASB }\end{array}$ & $\begin{array}{l}\text { Not directly relevant to risk, unless the company has committed to } \\
\text { these things (e.g. to shareholders and community through its } \\
\text { sustainability policy) but useful background for items that assurance } \\
\text { providers need to consider if conducting an assurance engagement. }\end{array}$ \\
\hline $\begin{array}{l}\text { Handbook of } \\
\text { International } \\
\text { Quality Control, } \\
\text { Auditing, Review, } \\
\text { Other Assurance, } \\
\text { and Related } \\
\text { Services } \\
\text { Pronouncements } \\
\text { (IFAC 2012) }\end{array}$ & $\begin{array}{l}\text { International } \\
\text { Federation of } \\
\text { Accountants }\end{array}$ & $\begin{array}{l}\text { Collation of international standards applicable to internal and external } \\
\text { audits, assurance and review engagements and their quality control. }\end{array}$ \\
\hline $\begin{array}{l}\text { ISO 31000:2018 } \\
\text { Risk } \\
\text { Management } \\
\text { (ISO 2018) }\end{array}$ & $\begin{array}{l}\text { International } \\
\text { Organization } \\
\text { for } \\
\text { Standardization }\end{array}$ & $\begin{array}{l}\text { Risk is a necessary part of doing business and in a world where } \\
\text { enormous amounts of data are being processed at increasingly rapid } \\
\text { rates, identifying and mitigating risks is a challenge for any company. } \\
\text { Many contracts and insurance agreements require solid evidence of } \\
\text { good risk management practice. ISO } 31000 \text { provides direction on how }\end{array}$ \\
\hline $\begin{array}{l}\text { AS/NZS ISO } \\
31000: 2009 \text { Risk } \\
\text { Management - } \\
\text { Principles and } \\
\text { Guidelines } \\
\text { (Standards } \\
\text { Australia 2010) }\end{array}$ & $\begin{array}{l}\text { Standards } \\
\text { Australia \& } \\
\text { Standards New } \\
\text { Zealand }\end{array}$ & $\begin{array}{l}\text { companies can integrate risk-based decision-making into an } \\
\text { organisation's governance, planning, management, reporting, policies, } \\
\text { values and culture. It is an open, principles-based system, meaning it } \\
\text { enables organisations to apply the principles in the standard to the } \\
\text { organisational context. }\end{array}$ \\
\hline $\begin{array}{l}\text { A Risk } \\
\text { Practitioner's } \\
\text { Guide to ISO } \\
\text { 31000: } 2018 \\
\text { (IRM 2018) }\end{array}$ & $\begin{array}{l}\text { Institute of Risk } \\
\text { Management } \\
\text { (IRM) }\end{array}$ & \\
\hline
\end{tabular}




\begin{tabular}{|c|c|c|}
\hline Name & Issued by & Summary of contents and aim \\
\hline \multirow[t]{2}{*}{$\begin{array}{l}\text { AASB/IFRS (AASB } \\
\text { 2018a, AASB } \\
2018 b)\end{array}$} & $\begin{array}{l}\text { Australian } \\
\text { Government: } \\
\text { Australian } \\
\text { Accounting } \\
\text { Standards } \\
\text { Board (AASB) }\end{array}$ & $\begin{array}{l}\text { The AASB is committed to developing, in the public interest, a single } \\
\text { set of high quality, understandable accounting standards that require } \\
\text { transparent and comparable information in general purpose financial } \\
\text { statements. The focus of these standards therefore is the creation and } \\
\text { reporting of financial information. }\end{array}$ \\
\hline & & $\begin{array}{l}\text { In accordance with the Financial Reporting Council Strategic Direction } \\
\text { given to the AASB in } 20021 \text { and the AUASB in 20052, the AASB has } \\
\text { adopted International Financial Reporting Standards (IFRS Standards) } \\
\text { as the basis for creating their standards. }\end{array}$ \\
\hline \multirow{4}{*}{$\begin{array}{l}\text { ASX Corporate } \\
\text { Governance } \\
\text { Guidelines - 3rd } \\
\text { Edition } \\
\text { (ASX 2014a) }\end{array}$} & ASX Corporate & The ASX Corporate Governance Council Principles and \\
\hline & Governance & Recommendations were introduced in 2003 and recommend \\
\hline & Council & $\begin{array}{l}29 \text { corporate governance practices for entities listed on the ASX. They } \\
\text { are not compulsory, but use an 'if not, why not' approach. Each } \\
\text { ASX-listed entity must provide the ASX, with its annual report, a } \\
\text { completed Appendix 4G, which has a key to where the various } \\
\text { disclosures suggested in the recommendations, or required under } \\
\text { Listing Rule 4.10.3, can be found. }\end{array}$ \\
\hline & & $\begin{array}{l}\text { Principle } 7 \text { provides four recommendations on how to recognise and } \\
\text { manage risk. }\end{array}$ \\
\hline $\begin{array}{l}\text { AICD Corporate } \\
\text { Governance } \\
\text { Framework } \\
\text { (AICD 2018b) }\end{array}$ & $\begin{array}{l}\text { Australian } \\
\text { Institute of } \\
\text { Company } \\
\text { Directors }\end{array}$ & $\begin{array}{l}\text { The four quadrants Framework depicts the four key areas of focus and } \\
\text { engagement applying to every individual director: individual, board, } \\
\text { organisational and stakeholder. Each quadrant is divided into a number } \\
\text { of slices representing director practices essential to the quadrant } \\
\text { focus. It includes sections on risk, assurance, compliance and } \\
\text { competence. }\end{array}$ \\
\hline $\begin{array}{l}\text { COBIT } \\
\text { Framework } \\
\text { (ISACA 2018) }\end{array}$ & ISACA & $\begin{array}{l}\text { Control Objectives for Information and Related Technologies is a } \\
\text { good-practice framework created by international professional } \\
\text { association ISACA for information technology (IT) management and IT } \\
\text { governance. It provides a comprehensive framework that assists } \\
\text { enterprises in achieving their objectives for the governance and } \\
\text { management of enterprise IT. Simply stated, it helps enterprises create } \\
\text { optimal value from IT by maintaining a balance between realising } \\
\text { benefits and optimising risk levels and resource use. COBIT } 5 \text { enables IT } \\
\text { to be governed and managed in a holistic manner for the entire } \\
\text { enterprise, taking in the full end-to-end business and IT functional } \\
\text { areas of responsibility, considering the IT-related interests of internal } \\
\text { and external stakeholders. COBIT } 5 \text { is generic and useful for enterprises } \\
\text { of all sizes, whether commercial, not-for-profit or in the public sector. }\end{array}$ \\
\hline $\begin{array}{l}\text { Global Reporting } \\
\text { Initiative } \\
\text { (GRI 2013) }\end{array}$ & & $\begin{array}{l}\text { The GRI promotes the use of sustainability reporting as a way for } \\
\text { organisations to become more sustainable and contribute to a } \\
\text { sustainable global economy. GRI's mission is to make sustainability } \\
\text { reporting standard practice. To enable all companies and organisations } \\
\text { to report their economic, environmental, social and governance } \\
\text { performance, GRI produces free sustainability reporting guidelines. }\end{array}$ \\
\hline
\end{tabular}

The AICD's director update (AICD 2018a) gives a general, contemporary feel for what draws the attention of directors. It is a long list of topics which, if managed according to the advice, will keep most lawyers and accountants busy. What's missing from the AICD's director updates and from the list of standards above is guidance on assurance of mining specific technical and operational risk. This leaves a huge gap in the current 
assurance framework for most mining company board audit and risk committees and their assurance providers. There also appears to be no training for mining experts to create this service in tandem with the financial and legal assurance traditionally provided.

\subsection{Environmental social governance and the global reporting initiative}

Global leadership from people like the CEO of Blackrock (the world's largest asset manager with USD 6 trillion in assets), Larry Fink, has increased pressure on companies around the world to lift standards on ESG (which includes safety and risk management).

"Society is demanding that companies, both public and private, serve a social purpose. To prosper over time, every company must not only deliver financial performance, but also show how it makes a positive contribution to society. Companies must benefit all of their stakeholders, including shareholders, employees, customers, and the communities in which they operate. Without a sense of purpose, no company, either public or private, can achieve its full potential. It will ultimately lose the license to operate from key stakeholders" (Fink 2018).

ESG is also well articulated by the ICMM. "In May 2008, member companies committed to report on their sustainable development performance in line with the Global Reporting Initiative (GRI) Sustainability Reporting Guidelines. In 2013, member companies reaffirmed their support for GRI by committing to report in accordance with the core option of GRI's G4 guidelines" (ICMM 2018; GRI 2013, 2015, 2018). For those who don't know, GRI G4 is a guideline of reporting principles and standard disclosures for informing markets and societies on sustainability matters. It is called G4 as it is the fourth update of the GRI Sustainability Reporting Guidelines (GRI 2015). Mining and metals sector specific disclosures are also required (GRI 2013). The "Global Reporting Initiative framework is the most commonly adopted international framework (72 companies)" (AICD 2018a, p. 14).

\subsubsection{What's in the GRI-G4 assurance?}

ESG reporting and assurance is mainly focussed on services provided by the Big 4 accounting firms. These tend to be based on audits against standards for the topics summarised below (GRI 2018):

- Occupational health and safety (International Labour Organization Convention 176 (ILO 1995)).

- Emergency preparedness.

- Environment.

- Compliance with laws and regulations.

- Resettlement and closure planning.

- Emissions.

- Climate change and/or carbon management (implicit).

- Human rights and indigenous rights.

- Industrial relations and collective bargaining.

- Anti-corruption and anti-competitive behaviour.

- Economic benefits to the jurisdiction/community.

- Diversity, equal opportunity and equal pay.

- Materials stewardship.

There are so many categories and it is not surprising that audit and risk committees struggle to provide appropriate oversight over the effective management of technical and operational risks associated with the act of mining. 


\subsection{ESG in mature, multinational mining companies}

Companies such as BHP, Rio Tinto, South 32, Glencore, Newcrest, Newmont, etc. have mature governance frameworks that comply with ESG guidance (set out in exchange listing rules such as on the NYSX and LSX). These mature companies are also signatories to various public commitments and are voluntarily committed to other initiatives, such as the ICMM, Extractive Industries Transparency Initiative and UN Global Compact (Figure 1). These frameworks promulgate the GRI Key Performance Indicators (KPIs) which major multinationals transparently report against in order to obtain high GRI scores from ratings agencies ( 5 stars being the best). These ratings are used by ethical investment groups such as university endowment funds, pension funds, venture capital groups and banks to determine who should receive funding and at what weighted average cost of capital (WACC). The implication is that it should be easier and cheaper to obtain investment if your company has a high GRI score. The KPIs reported may also be linked to executive pay in these organisations, driving better executive behaviour through the hip pocket.

Proxy advisers (e.g. CGI Glass Lewis, Ownership Matters and ISS) have a significant influence on mining company annual general meeting voting outcomes. If a mining company has poor ESG practices and/or transparency, proxy advisers influence shareholders to vote against certain board resolutions. In a worst case scenario, some proxy advisers (e.g. ISS) can instigate class action litigation on behalf of shareholders if a company is seen to have made gross errors of judgement which could have been avoided with more mature governance and through greater diligence of directors.

CGI Glass Lewis (Doyle 2018, p. 18) states:

"When a substantial environmental or social risk has been ignored or inadequately addressed, we may recommend voting against responsible members of the risk committee or its equivalent (including an environmental or sustainability committee), or in favour of a shareholder proposal that addresses the company's failure to address such risks, particularly around providing more disclosure and reporting regarding the risk and related mitigation initiatives".

GRI ESG reporting is a worthy global initiative but it has holes. More work needs to be done to educate assurance providers, directors and proxy advisers on the need for mining deep domain experts to provide independent assurance on whether companies are managing the disaster-causing risks of mining, such as geotechnical engineering risks.

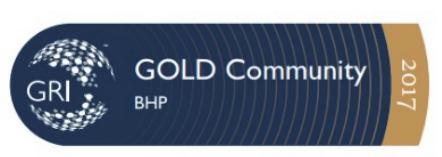

VILUNTARY

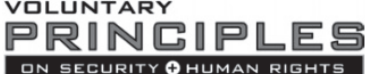

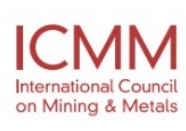

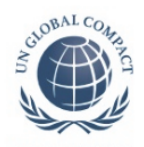

WE SUPPORT

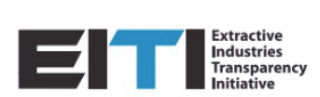

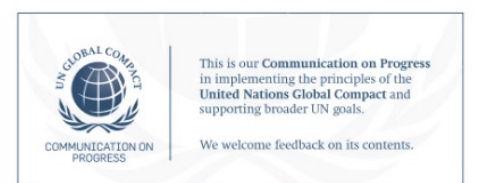

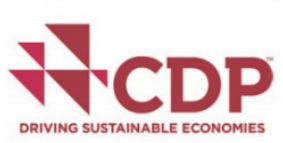

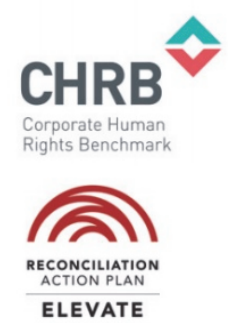

Figure 1 Example of voluntary initiatives and public commitments made by tier 1 mining companies (BHP 2017, p. 9)

A commercial motivator for ESG reporting is the link between strong ESG and a lower WACC. A lower WACC means a lower discount rate applied to valuations, resulting in higher valuations which lead to higher share prices (Ker 2018b). The incentive for mining executives to obtain high ESG scores may have led to the ESG system being focussed on things which are easy to measure, but there is a saying: "Not everything that can be counted counts, and not everything that counts can be counted" (Gittins 2018). This is why mining STEM professionals with deep domain expertise are important - they know what counts. 


\section{$4 \quad$ What does good technical and operational risk assurance look like?}

Risk-intelligent companies follow nine principles (Deloitte 2009) (Figure 2):

1. A common definition of risk, which addresses both value preservation and value creation, is used consistently throughout the organisation.

2. A common risk framework supported by appropriate standards is used throughout the organisation to manage risks.

3. Key roles, responsibilities and authority relating to risk management are clearly defined and delineated within the organisation.

4. A common risk management infrastructure is used to support the business units and functions in the performance of their risk responsibilities.

5. Governing bodies (e.g. boards, audit committees, etc.) have appropriate transparency and visibility into the organisation's risk management practices to discharge their responsibilities.

6. Executive management is charged with primary responsibility for designing, implementing and maintaining an effective risk program.

7. Business units are responsible for the performance of their business and the management of risks they take within the risk framework established by executive management.

8. Certain functions (e.g. HR, finance, IT, tax, legal, etc.) have a pervasive impact on the business and provide support to the business units as it relates to the organisation's risk program.

9. Certain functions (e.g. internal audit, risk management, compliance, etc.) provide objective assurance as well as monitor and report on the effectiveness of an organisation's risk program to governing bodies and executive management.

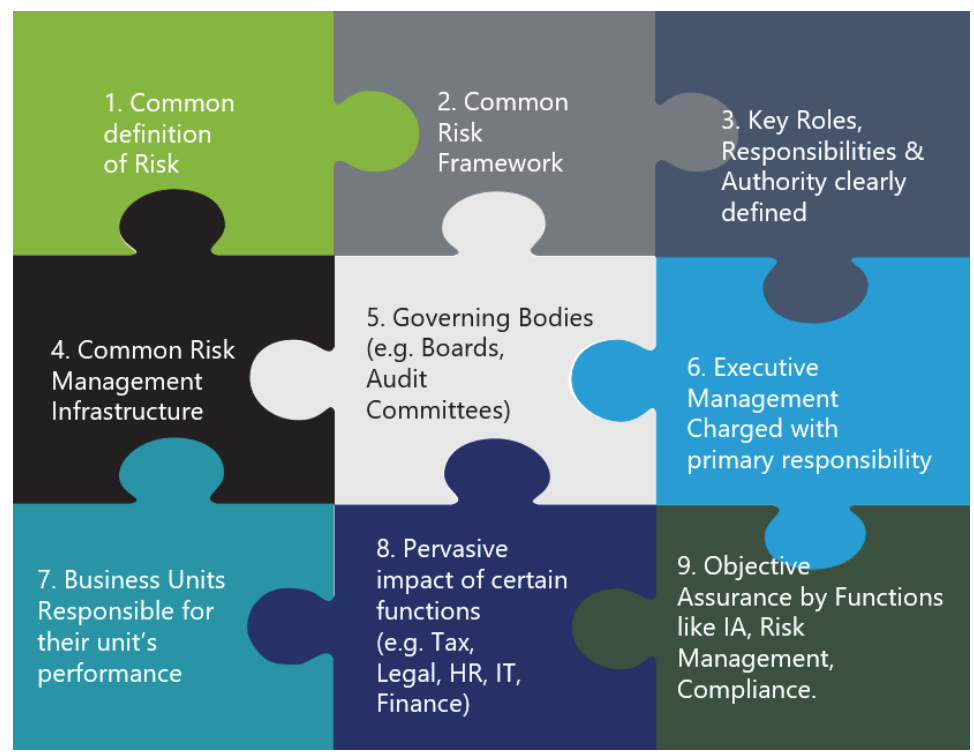

Figure 2 Nine principles of a risk-intelligent enterprise (Deloitte 2009)

This paper focuses on principles 5 and 9 , which is the board's role in maintaining a degree of ownership of risk and thus resourcing an appropriate level of internal audit, external audit and assurance activities. Although the Big 4 accounting firms' suggestions on risk management are sound, in practice they fail to deliver any kind of assurance on technical and operational risk in mining. For example, when undertaking independent auditor's reports, external auditors must provide a narrative on key audit matters (KAMs) (AASB 2015), which are meant to cover any material risks for the company which may have an adverse material financial impact. KAMs could arguably include commentary on the Joint Ore Reserves Committee (JORC) Code (JORC 2012) 
compliance (as required by ASX Listing Rules and Chapter 5 (ASX 2013, ASX 2014b) of the mineral resource and ore reserve upon which the mining company's valuation is partly based (as well as on property plant and equipment, goodwill, cash, etc.).

If risk control matrices (RCMs) on JORC compliance (explained in 4.1) were created as part of the assurance process (which they generally are not), technical and operational risk could be appropriately considered at that point, using independent expert reports. If this process was undertaken, there would be greater consideration given to what could go wrong and the impact this may have on the company's ability to meet market guidance, its triple bottom line, reputation and risk of litigation. This would then provide impetus for the board to ensure appropriate resources are made available to manage these risks.

One method used by internal audit functions for provision of assurance of effective management of risk is the three lines of defence (3LOD) assurance mapping.

\subsection{Three lines of defence}

Auditors use processes known as 3LoD board assurance and RCM to map out key risks, key controls and their effectiveness assessments. "When used in conjunction with assurance maps, a documented ' 3 Lines of Defence' model can help inform the Board of Directors, Audit Committee and Senior Management how well the organisation's assurance functions are operating" (IIA 2018). The first line of defence is "concerned with management controls and generally has a real-time focus" (IIA 2018). The second line of defence "centres on risk oversight and involves some degree of real-time activity, with a mandate to review 1st Line of Defence activities" (IIA 2018). The third line of defence "involves independent assurance that evaluates the adequacy and effectiveness of both 1st Line and 2nd Line risk management approaches" (IIA 2018) (Figure 3).

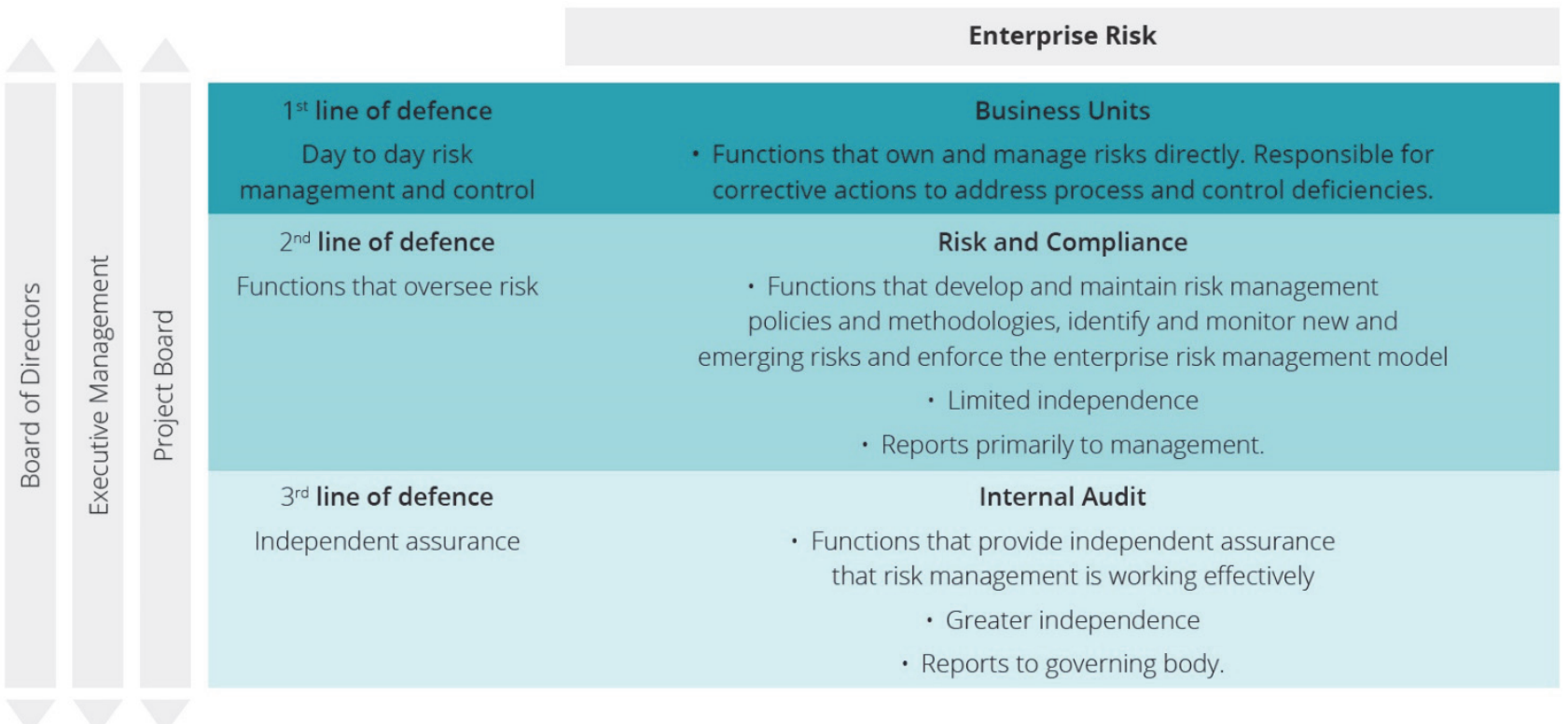

Figure 3 Three lines of defence (Deloitte 2016)

For specific geotechnical risks, 3LoD and/or RCM assurance could be provided for specific geotechnical risks such as TSF stability, seismicity risk management, ground control management (i.e. to prevent rockfalls and pit slips), mine fill management (i.e. to prevent paste/hydraulic fill inrushes), etc.

Greater transparency on key controls effectiveness for prevention of the types of incidents that can lead to mine disasters would significantly improve board attention and could serve as evidence of due diligence when defending directors if an adverse event should occur. It could be argued that the ICMM's Health \& Safety Critical Control Management Guide (ICMM 2015) already sets out a process to provide assurance (verification) of critical controls. While it is a good document, it covers critical controls for all material unwanted events (MUEs) from a statistical analysis of past accidents (Figure 4) and does not go into any detail 
on each risk or the competencies of those who must provide the assurance/verification for each type of MUE. It is possible that assurance can become a simplistic, tick box exercise if carried out by unqualified people using generic guidance.

Understanding mining risk requires technical and operational expertise from risk-trained mining engineering, life-of-mine planning, geotechnical engineering, geology and metallurgy experts. These professionals need to work alongside traditional assurance providers to develop new ways to provide transparency, accountability and assurance to mining company boards. Risks are never definite, so market disclosure of these risks may not be required, per ASX Listing Rules 3.1 and 3.1A (ASX 2013, n.d.) but they should certainly be proactively managed. This requires appropriate resources (i.e. access to mining expertise either in-house or as consultants).

\begin{tabular}{|l|}
\hline MINING AND METALS MUEs \\
\hline Aviation \\
\hline Underground ground control \\
\hline Underground fire/explosion \\
\hline Heavy mining equipment \\
\hline Dropped objects \\
\hline Pressurized systems \\
\hline Confined spaces \\
\hline Inrush/inundation \\
\hline Explosives \\
\hline Highwall stability \\
\hline Flammable gas \\
\hline Light vehicles \\
\hline Work at height \\
\hline Electricity \\
\hline Hazardous materials \\
\hline
\end{tabular}

Figure 4 Material unwanted events (MUEs) in mining, based on historical analysis (ICMM 2015, p. 9)

\section{$5 \quad$ Risks associated with the digital transformation of mining and how this may impact on the management of technical and operational risk}

\subsection{Competency framework - how will future skills impact mines safety and productivity?}

Quinlan (2014) and Kenner (2009) note the importance of the competency framework for managers and regulators of mines as a major factor in preventing mine disasters. Reduction of competency requirements was identified as a major causal factor of the Pike River (Panckhurst et al. 2012) and Beaconsfield (Chandler 2009) disasters.

The digital transformation of mining brings new risks to the mining industry, including that mines are increasingly going to be designed and managed by non-traditional disciplines who are domain experts in autonomous operations, artificial intelligence, cyber risk and other ICT related fields. How can we be sure those who design, run and regulate our mines have appropriate expertise to ensure lessons from the past are not lost but also to ensure risks inherent in the digital mine are being appropriately identified and managed?

\subsection{Artificial intelligence, machine learning and cyber risk}

The digital mine will be significantly automated and interconnected thanks to the convergence of information technology (IT) and operational technology (i.e. IT-OT convergence) enabling real-time engineered data science (artificial intelligence and machine learning ( $\mathrm{Al} / \mathrm{ML})$ ) optimisation via improved communications infrastructure, with all machines and platforms accessible through the cloud/internet. Holistic optimisation and removal of siloes will result in more efficient, better managed mines where risks are more thoroughly 
and expediently mitigated, as long as the technology is working. It is hoped the digital transformation of mining, which includes automation, will improve assurance of technical and operational risks from the safety of remote operation centres.

Quinlan (2014, p. 39) states that infrequently revised laws have "failed to keep pace with changes in work including changes in technology and work organisation". With $\mathrm{Al} / \mathrm{ML}$ increasingly enabling systems and processes to become automated, there needs to be ongoing change risk management around the boundaries of $\mathrm{Al} / \mathrm{ML}$ and human expert decision-making. Al expert Tegmark (2017) highlights the risk of allowing $\mathrm{Al} / \mathrm{ML}$ to have total control and Good (1965), as quoted in Tegmark (2017, p. 134), states: "the first ultraintelligent machine is the last invention that man need ever make, provided that the machine is docile enough to tell us how to keep it under control". There is also the risk posed by hackers who may override systems and change algorithms. What are the technical and operational risks associated with detected and undetected external interference with mining systems? What does good cyber risk management look like in a connected mine? Are the right people involved with systems design and oversight?

\section{Conclusion}

There are gaps in the current auditing framework and board assurance for management of technical and operational risk in mining. For the mining industry to retain its SLTO, board level assurance of technical and operational risks - not just legal and financial risks - is imperative. In order to do this, mining company boards and executive teams must have appropriate representation of mining experts in their ranks. Many major multinational mining companies have insufficient risk-educated geologists, mining engineers, geotechnical engineers and/or metallurgists on their board or in their executive team. In some cases, these companies have had to defend themselves against class actions and/or regulatory action as a result of adverse outcomes, including incidents that could have been prevented by greater due diligence on geotechnical risk.

Moving forward, corporate governance thought leaders (e.g. AICD and proxy advisers) need to be educated. Understanding risk in mining requires technical and operational expertise in mining engineering, life-of-mine planning, geotechnical engineering, geology and metallurgy. These professionals need to work alongside traditional risk practitioners and assurance providers to develop new ways to provide transparency, accountability and assurance to mining company boards.

\section{Acknowledgement}

We thank Jo Heyes (mining engineer specialising in mine closure at BHP) and David O'Brien (ESG consultant at MBS Environmental) for peer reviewing our paper and providing valuable feedback.

\section{References}

AASB 2015, Auditing Standard ASA701 - Communicating Key Audit Matters in the Independent Auditor's Report, Australian Accounting Standards Board, https://www.auasb.gov.au/admin/file/content102/c3/ASA_701_2015.pdf

AASB 2018a, The Australian Accounting Standards Board, Australian Accounting Standards Board, https://www.aasb.gov.au/AASBBoard.aspx

AASB 2018b, Corporate Plan 2018-2019, Australian Accounting Standards Board, https://www.aasb.gov.au/ admin/file/content102/c3/AASB-AUASB_CorporatePlan_2018-19.pdf

AICD 2018a, Essential Director Update: 18, Australian Institute of Company Directors, https://aicd.companydirectors.com.au/ events/essential-director-update

AICD 2018b, Company Directors Corporate Governance Framework, Australian Institute of Company Directors, http://www. companydirectors.com.au/director-resource-centre/corporate-governance-framework/framework

ASX 2013, ASX Listing Rules - Guidance Note 31, ASX, Sydney, viewed 19 February 2019, https://www.asx.com.au/documents/ rules/gn31_reporting_on_mining_activities.pdf

ASX 2014a, Corporate Governance Principles and Recommendations, 3rd edn, ASX Corporate Governance Council, https://www.asx.com.au/documents/asx-compliance/cgc-principles-and-recommendations-3rd-edn.pdf

ASX 2014b, 'Chapter 5: additional reporting on mining and oil and gas production and exploration activities', ASX Listing Rules, ASX, Sydney, viewed 19 February 2019, https://www.asx.com.au/documents/rules/Chapter05.pdf

ASX n.d., Abridged Continuous Disclosure Guide, ASX, Sydney, viewed 19 February 2019, https://www.asx.com.au/documents/ about/abridged-continuous-disclosure-guide-clean-copy.pdf 
Atkins, A \& Webster-Smith, T 2011, 'OHS management systems for geotechnical risk', in Y Potvin (ed.), Proceedings of the Fourth International Seminar on Strategic versus Tactical Approaches in Mining, Australian Centre for Geomechanics, Perth, pp. 367-375.

Atkins, A, Morris, T, Jones, O \& Bell, S 2016, 'Progress of harmonisation of WHS laws in Australian mining', Aus/MM Bulletin, viewed 16 September 2018, https://www.ausimmbulletin.com/feature/progress-harmonisation-workplace-health-safety-laws -australian-mining/

AUASB 2013, Auditing Standard ASA 265 - Communicating Deficiencies in Internal Control to those Charged with Governance and Management, Auditing and Assurance Standards Board, https://www.auasb.gov.au/admin/file/content102/c3/Nov13_ Compiled_Auditing_Standard_ASA_265.pdf

AUASB 2017a, Auditing Standard ASA 260 - Communication with those Charged with Governance, Auditing and Assurance Standards Board, https://www.auasb.gov.au/admin/file/content102/c3/ASA_260_Compiled_2017.pdf

AUASB 2017b, Standards on Assurance Engagements, Auditing and Assurance Standards Board, https://www.auasb.gov.au/ Pronouncements/Standards-on-Assurance-Engagements.aspx

Bailey, J 2003, Findings and Recommendations: Inquest into the Deaths of R Bodkin; M House; S Osman; and C Lloyd-Jones; on the 24th November 1999 at the E26 Lift 1 Mine, Northparkes Mines, Parkes, New South Wales, NSW Coroners Court.

Baxt, RB 2012, Duties and Responsibilities of Directors and Officers, 20th edn, Australian Institute of Company Directors.

BHP 2017, BHP Sustainability Report 2017, https://www.bhp.com/-/media/documents/investors/annual-reports/2017/ bhpsustainabilityreport2017.pdf?la=en

Chandler, R 2009, In the Matter of the Coroners Act 1995 and in the Matter of an Inquest Touching the Death of Larry Paul Knight, Magistrates Court of Tasmania - Coronial Division, http://eagcg.org/common/pdf/Beaconsfield.pdf

Deloitte 2009, Take the Right Steps: 9 Principles for Building the Risk Intelligent Enterprise, https://www2.deloitte.com/content/ dam/Deloitte/in/Documents/risk/Board\%20of\%20Directors/in-gc-putting-risk-in-the-comfort-zone-nine-principles-for-riskintelligent-enterprises-noexp.pdf

Deloitte 2016, Project Risk Management - Applying the Three Lines of Defence Model to Project Risk Management, https://www2.deloitte.com/content/dam/Deloitte/au/Documents/risk/deloitte-au-rs-project-risk-management-310117.pdf

DMP 2000a, 'Backfilling of underground voids', MINESAFE, vol. 11, no. 2, http://www.dmp.wa.gov.au/Documents/Safety/ RS_MineSafe_Jun00.pdf

DMP 2000b, 'Air blast hazards in U/G mines', MINESAFE, vol. 11, no. 2, http://www.dmp.wa.gov.au/Documents/Safety/ RS_MineSafe_Jun00.pdf

Doyle, T 2018, The conflicted role of proxy advisors, American Council for Capital Formation, http://accfcorpgov.org/wpcontent/uploads/2018/05/ACCF_The-Conflicted-Role-of-Proxy-Advisors.pdf

Dyson, N 2017, 'Seismic event shuts Cadia', Australian Mining Monthly, https://www.miningmonthly.com/preciousmetals/news/1308418/seismic-event-shuts-cadia

Fink, L 2018, Larry Fink's 2019 Letter to CEOs - Purpose \& Profit, Blackrock, https://www.blackrock.com/corporate/investorrelations/larry-fink-ceo-letter

Gittins, R 2018, 'Bank's misbehaviour shows power of KPIs', The Sydney Morning Herald, https://www.smh.com.au/business/theeconomy/banks-commission-ross-gittins-metrics-kpi-20180424-p4zbbj.html

Good, IJ 1966, 'Speculations concerning the first ultraintelligent machine', Advances in Computers, vol. 6, pp. 31-88.

GRI 2013, The External Assurance of Sustainability Reporting, Global Reporting Initiative Research \& Development Series, https://www.globalreporting.org/resourcelibrary/GRI-Assurance.pdf

GRI 2015, GRI-G4 Part 1 Reporting Principles and Standard Disclosures, Global Reporting Initiative, Amsterdam, viewed 19 February 2019, https://www.globalreporting.org/resourcelibrary/GRIG4-Part1-Reporting-Principles-and-Standard-Disclosures.pdf

GRI 2018, GRI-G4 Mining and Metals Sector Disclosures, Global Reporting Initiative, Amsterdam, viewed 19 February 2019, https://www.globalreporting.org/Documents/ResourceArchives/GRI-G4-Mining-and-Metals-Sector-Disclosures.pdf

Hair, J 2016, Moura Number Four Coal Mine Victims Remembered 30 Years on, ABC, http://www.abc.net.au/news/2016-0716/moura-number-four-coal-mine-victims-remembered-30-years-on/7633806

Hebblewhite, BK 2003, 'Northparkes findings-the implications for geotechnical professionals in the mining industry', in BK Hebblewhite (ed.), Proceedings of the 1st Australasian Ground Control in Mining Conference, UNSW Sydney, pp. 3-10.

Hope 2002, Annual Report 2001/2002 - Bronzewing Mine Site - Deaths of Shane Hamill, Troy Terrence Woodard and Timothy Lee Bell, Office of the State Coroner Western Australia, Perth, http://www.parliament.wa.gov.au/publications/tabledpapers.nsf/ displaypaper/3620450a56a552a06a360d3c48256c6800274297/\$file/coroner2002.pdf

ICMM 2015, Health \& Safety Critical Control Management Guide - Good Practice Guide, ICMM, https://www.icmm.com/ website/publications/pdfs/health-and-safety/8570.pdf

ICMM 2018, Member Reporting and Governance, ICMM, https://www.icmm.com/en-gb/members/member-reporting-andperformance

IFAC 2012, Handbook of International Quality Control, Auditing, Review, Other Assurance, and Related Services Pronouncements, International Federation of Accountants, Geneva, https://www.ifac.org/publications-resources/2012-handbookinternational-quality-control-auditing-review-other-assurance-a

IIA 2017, International Standards for the Professional Practice of Internal Auditing (Standards), The Institute of Internal Auditors, http://iia.org.au/sf_docs/default-source/quality/ippf-standards-2017.pdf?sfvrsn=2

IIA 2018, Factsheet: '3 Lines of Defence' Combined Assurance Model, The Institute of Internal Auditors, http://iia.org.au/sf_docs/default-source/technical-resources/2018-fact-sheets/three-lines-of-defence.pdf?sfvrsn=2 
ILO 1995, C176 - Safety and Health in Mines Convention, 1995 (No. 176), ILO, Geneva, viewed 19 February 2019, https://www.ilo.org/dyn/normlex/en/f?p=NORMLEXPUB:12100:0::NO::P12100_ILO_CODE:C176

IRM 2018, A Risk Practitioner's Guide to ISO 31000 - 2018, Institute of Risk Management, https://www.theirm.org/media/ 3513119/IRM-Report-ISO-31000-2018-v3.pdf

ISACA 2018, COBIT Framework, Information Systems Audit and Control Association, http://www.isaca.org/Knowledge-Center/COBIT/ Pages/Overview.aspx

ISO 2007, ISO18001:2007 Occupational Health and Safety Management System, International Organization for Standardization, Geneva.

ISO 2008, ISO 45001:2008 Occupational Health and Safety Management Systems - Requirements with Guidance for Use, International Organization for Standardization, Geneva, viewed 15 February 2019, https://www.iso.org/standard/63787.html

ISO 2018, ISO 31000:2018 Risk Management, International Organization for Standardization, Geneva, viewed 15 February 2019, https://www.iso.org/iso-31000-risk-management.html

JORC 2012, The JORC Code, The Australasian Institute of Mining and Metallurgy, Melbourne, viewed 15 February 2019 , http://www.jorc.org/docs/JORC_code_2012.pdf

Kenner, J 2009, Review of the Mines Safety and Inspection Act 1994, Western Australian Industrial Relations Commission, http://forms.wairc.wa.gov.au/files/DiscussionPapers/MI_Act_KennerReview1994.pdf

Ker, P 2018a, 'More than 3000 pursue Samarco in class action', Australian Financial Review, https://www.afr.com/business/ mining/more-than-3000-pursue-bhp-in-samarco-class-action-20180722-h12zrb

Ker, P 2018b, 'After Barrick and Randgold, does Newcrest Mining need a mega-merger of its own?', Australian Financial Review, https://www.afr.com/business/mining/does-newcrest-need-a-megamerger-of-its-own-20181004-h167qu

Mayer, C 2013, Firm Commitment: Why the Corporation is Failing us and how to Restore Trust in it, Oxford University Press, Oxford.

Morgenstern, NR, Vick, SG, Watts, BD \& Viotti, C 2016, The Fundao Tailings Dam Investigation, http://fundaoinvestigation.com/

Newcrest Mining Limited 2018, Seismic Event Near Cadia Operation, media release, http://www.newcrest.com.au/news-andinformation/media-releases/seismic-event-near-cadia-operation

Panckhurst, G, Bell, S \& Henry, D 2012, Royal Commission on the Pike River Coal Mine Tragedy, https://pikeriver.royalcommission. govt.nz/Volume-One---Contents

Quinlan, M 2014, Ten Pathways to Death and Disaster: Learning from Fatal Incidents in Mines and Other High Hazard Workplaces, The Federation Press, Alexandria.

Safe Work Australia 2016, Model Work Health and Safety Bill, Safe Work Australia, Canberra, viewed 19 February 2019 , https://www.safeworkaustralia.gov.au/system/files/documents/1702/model-whs-act-21march2016.pdf

SIMTARS 1999, Northparkes Airblast 1999, Safety in Mines Testing and Research Station, http://www.mineaccidents.com.au/mineaccident/186/northparkes-airblast-1999

Slater \& Gordon 2016, Newcrest Mining Class Action, https://www.slatergordon.com.au/class-actions/past-class-actions/newcrestmining

Stacey, TR, Terbrugge, RJ \& Wesseloo, J 2007, 'Risk as rock engineering design criterion', in Y Potvin, J Hadjigeorgiou \& TR Stacey (eds), Challenges in Deep and High Stress Mining, Australian Centre for Geomechanics, Perth.

Standards Australia 2001, AS/NZS 4801:2001 Occupational Health and Safety Management Systems - Specification with Guidance for Use, Standards Australia, Sydney, viewed 15 February 2019, https://www.saiglobal.com/PDFTemp/Previews/OSH/as/ as4000/4800/4801.pdf

Standards Australia 2010, AS/NZS ISO 31000:2009 Risk Management Principles and Guidelines, Comcover, https://www.finance.gov.au/sites/default/files/COV_216905_Risk_Management_Fact_Sheet_FA3_23082010_0.pdf

Tegmark, M 2017, Life 3.0-Being Human in the Age of Artificial Intelligence, Knopf, New York.

UQR!SK 2018, Measuring Control Performance Master Practitioner Session, attended 2 November 2018, www.eait.uq.edu.au/cpd 